\section{KURIKULUM}

\section{KEPRIBADIAN SANTRI}

\section{PONDOK PESANTREN TANGGERANG BANTEN}

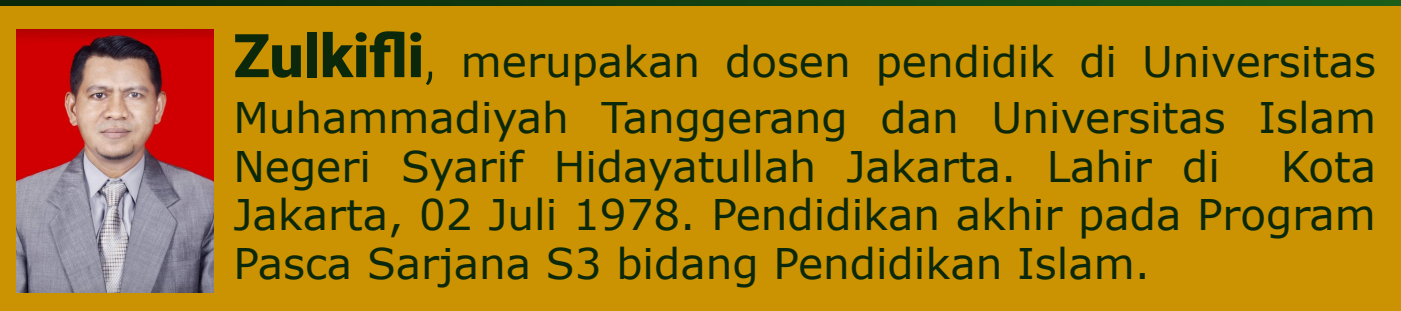

Pondok pesantren adalah lembaga pendidikan, keagamaan dan kemasyarakatan yang sudah sejak lama dikenal sebagai wahana pengembangan masyarakat (community development), telah terungkap dalam sejarah. Dengan orientasi tersebut, pondok pesantren telah mampu menunjukkan partisipasi aktifnya bersama-sama pemerintah dalam mensukseskan program-program pembangunan, lebih dalam hal itu kehidupan beragama dan mencerdaskan kehidupan bangsa berjalan dengan harmonis. Realitas perubahan zaman yang begitu cepat menuntut pesantren untuk melek terhadap arus perubahan yang begitu cepat dan tak terbendung. Integrasi kurikulum merupakan satu solusi yang tidak bisa ditawar lagi. Globalisasi yang menjadi corong perubahan itu harus diimbangi dengan sistem pesantren dalam inovasi pendidikannya. Inovasi pesantren dapat dilakukan dengan melakukan pembaharuan pada sektor kurikulumnya. Kurikulum pesantren setidaknya harus dapat memenuhi tuntutan kebutuhan santri dan masyarakat agar menghasilkan out put yang handal dan siap berkompetisi di tengah-tengah masyarakat. Untuk memenuhi tuntutan kebutuhan santri dan masyarakat, perlu dilakukan pembaharuan kurikulum pada tiga aspek yaitu; perencanaan, pelaksanaan dan evaluasi. Dalam buku ini secara khusus membahas tentang kurikulum kepribadian santri yang dikembangkan berdasarkan pengamatan yang mendalam terhadap apa yang dipraktekkan oleh beberapa pondok pesantren di wilayah Tangerang dalam rangka mengembangkan kepribadian para santrinya

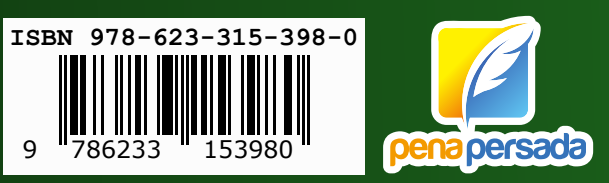

KURIKULUM

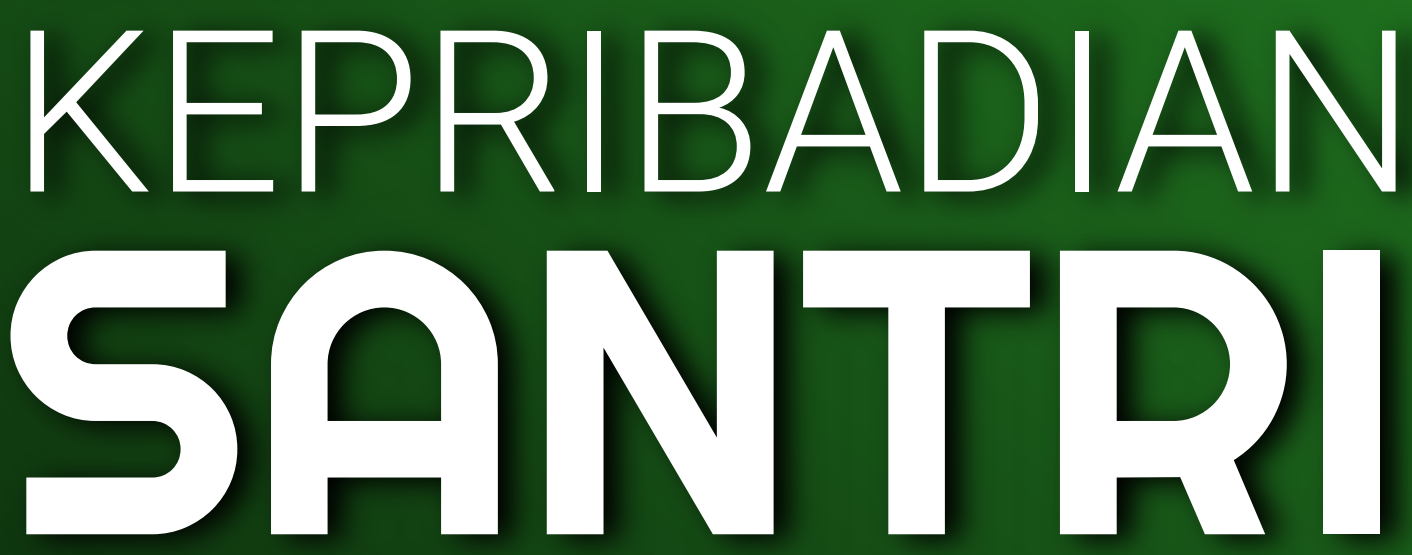

\section{PONDOK PESANTREN TANGGERANG BANTEN}




\title{
KURIKULUM KEPRIBADIAN SANTRI DI PONDOK PESANTREN TANGERANG BANTEN
}

\author{
ZULKIFLI
}

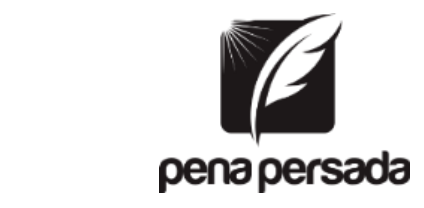

PENERBIT CV. PENA PERSADA 


\section{KURIKULUM KEPRIBADIAN SANTRI \\ DI PONDOK PESANTREN TANGERANG BANTEN}

Penulis:

Zulkifli

ISBN : 978-623-315-398-0

Editor:

Wiwit Kurniawan

Design Cover :

Retnani Nur Briliant

Layout :

Eka Safitry

\section{Penerbit CV. Pena Persada}

Redaksi :

Jl. Gerilya No. 292 Purwokerto Selatan, Kab. Banyumas

Jawa Tengah

Email : penerbit.penapersada@gmail.com

Website : penapersada.com Phone : (0281) 7771388

Anggota IKAPI

All right reserved

Cetakan pertama : 2021

Hak Cipta dilindungi oleh undang-undang. Dilarang memperbanyak karya tulis ini dalam bentuk apapun tanpa izin penerbit 


\section{KATA PENGANTAR}

Segala puji senantiasa kita panjatkan kehadirat Allah SWT, atas segala rahmat dan karunianya, akhirnya penulis dapat menyelesaikan penyusunan buku yang berjudul "KURIKULUM KEPRIBADIAN SANTRI DI PONDOK PESANTREN TANGERANG BANTEN". Saya menyadari bahwa tanpa bantuan dan bimbingan dari berbagai pihak sangatlah sulit bagi saya untuk menyelesaikan karya ini. Oleh karena itu, saya mengucapkan banyak terima kasih pada semua pihak yang telah membantu penyusunan buku ini. Sehingga buku ini bisa hadir di hadapan pembaca.

Implementasi kurikulum merupakan aktualisasi kurikulum dalam bentuk pembelajaran. Implementasi kurikulum dapat didefenisikan sebagai suatu proses penerapan ide, konsep, dan kebijakan kurikulum (kurikulum potensial) dalam suatu aktivitas pembelajaran sehingga peserta didik menguasai seperangkat kompetensi tertentu, sebagai hasil interaksi dengan lingkungan. Dalam hal ini, dapat dikemukakan bahwa implementasi kurikulum adalah operasionalisasi konsep kurikulum yang masih bersifat potensial atau tertulis menjadi aktual dalam bentuk kegiatan pembelajaran. Implementasi kurikulum adalah hasil terjemahan guru terhadap kurikulum sebagai rencana tertulis. Dalam buku ini membahas tentang kurikulum 
kepribadian santri yang dikembangkan berdasarkan pengamatan yang mendalam terhadap apa yang dipraktekkan oleh beberapa pondok pesantren di wilayah Tangerang dalam rangka mengembangkan kepribadian para santrinya

Penulis menyadari bahwa buku ini masih jauh dari kesempurnaan. Oleh karena itu kritik dan saran yang membangun sangat dibutuhkan guna penyempurnaan buku ini. Akhir kata saya berharap Allah SWT berkenan membalas segala kebaikan semua pihak yang telah membantu.

Penulis 


\section{DAFTAR ISI}

KATA PENGANTAR ….......................................................ii

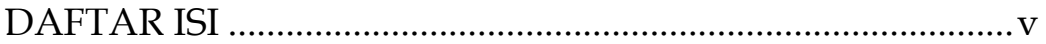

BAB I PENDAHULUAN ......................................................... 1

A. Sistem Pendidikan Pesantren ......................................... 1

B. Pengembangan Pendidikan Pesantren ....................... 8

BAB II PONPES AL-AMANAH AL-GONTORY.................... 15

A. Profil Al-Amanah Al-Gontory …………………....... 15

1. Sejarah Singkat Pondok Modern AlAmanah Al-Gontory ...........................................16

2. Latar Belakang Kurikulum Al-Amanah Al-

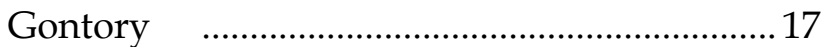

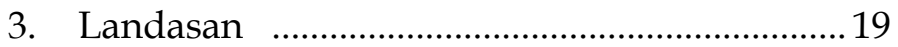

4. Prinsip-Prinsip Pengembangan dan

Pelaksanaan Kurikulum ........................................ 20

5. Visi, Misi, Tujuan dan Strategi Madrasah........27

6. Sasaran Dan Program .......................................... 32

B. Tujuan Perencanaan kurikulum kepribadian santri

C. Program kurikulum kepribadian santri di

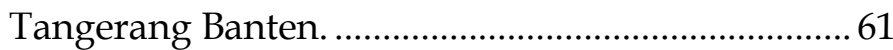

D. Proses Pelaksanaan Pembinaan Kurikulum Kepribadian Santri pada Ponpes Al-Amanah Al-Gontory Tangerang Banten..................................62 62 
E. Evaluasi Kurikulum Kepribadian Santri

F. Faktor-faktor pendukung dan penghambat kurikulum kepribadian santri.

G. Tingkat keberhasilan pelaksanaan kurikulum kepribadiaan santri di ponpes Al-Amanah AlGontory, 86

BAB III PONPES DAARUL QUR'AN

A. Profil Pondok Pesantren Daarul Qur'an

B. Tujuan Perencanaan kurikulum kepribadian santri

C. Program kurikulum kepribadian santri di Tangerang Banten. 106

D. Proses pelaksanaan pembinaan kurikulum kepribadian santri pada ponpes Daarul Qur'an Tangerang Banten

E. Evaluasi kurikulum kepribadian santri 108

F. Faktor-faktor Pendukung dan Penghambat Kurikulum Kepribadian Santri.

G. Tingkat Keberhasilan Pelaksanaan Kurikulum Kepribadiaan Santri Di Ponpes Daarul Qur'an ....123 BAB IV PONPES DAARUL HIKMAH 125

A. Profil Pondok Pesantren Daarul Hikmah. 125

B. Tujuan Perencanaan kurikulum kepribadian santri. 135 
C. Program kurikulum kepribadian santri di Tangerang Banten.

D. Proses pelaksanaan pembinaan kurikulum kepribadian santri pada ponpes Daarul Hikmah Tangerang Banten

E. Evaluasi kurikulum kepribadian santri 138

F. Faktor-faktor pendukung dan penghambat kurikulum kepribadian santri.

G. Tingkat keberhasilan pelaksanaan kurikulum kepribadian santri di ponpes Daarul Hikmah,.... 150 BAB V PONPES DAARUL MUTTAQIEN

A. Tujuan Perencanaan kurikulum kepribadian santri

B. Program kurikulum kepribadian santri di Tangerang Banten. 154

C. Proses pelaksanaan pembinaan kurikulum kepribadian santri pada ponpes Daarul Muttaqien Tangerang Banten.

D. Evaluasi kurikulum kepribadian santri.

BAB VI KURIKULUM PESANTREN DAN PESANTREN MASA DEPAN

A. Keunggulan Dan Keterbatasan Kurikulum 189

B. Format Pesantren Masa Depan 217

BAB VII PENUTUP 223 


\section{KURIKULUM KEPRIBADIAN SANTRI DI PONDOK PESANTREN TANGERANG BANTEN}




\section{BAB I}

\section{PENDAHULUAN}

\section{A. Sistem Pendidikan Pesantren}

Pesantren mempunyai peranan yang cukup signifikan dalam rangka Islamisasi wilayah nusantara. Hal ini sejalan dengan sejarah tumbuh dan berkembangnya pendidikan Islam di Indonesia. Bentuknya adalah dengan melestarikan ajaran-ajaran Islam melalui transmisi keilmuan para ulama kepada santinya. Reproduksi ulama' dalam memelihara tradisi keagamaan yang hidup di tengah-tengah masyarakat sangat kental. ${ }^{1}$ Kondisi yang demikian telah dibuktikannya sampai sekarang seperti yang telah di ketahui bersama.Pondok pesantren adalah lembaga pendidikan, keagamaan dan kemasyarakatan yang sudah sejak lama dikenal sebagai wahana pengembangan masyarakat (community development), telah terungkap dalam sejarah. Dengan orientasi tersebut,pondok pesantren telah mampu menunjukkan partisipasi aktifnya bersama-sama pemerintah dalam mensukseskan program-program pembangunan, lebih 
dalam hal itu kehidupan beragama dan pencerdasan kehidupan bangsa berjalan dengan harmonis. Dalam lembaran sejarah bangsa Indonesia, nama-nama tokoh pesantren semisal, KH. M. Hasyim Asy'ari, KH. Wahab Hasbullah, KH. Bisyri Syamsuri, KH. Syaifudin Zuhri, dan KH. A. Wahid Hasyim tercatat sebagai tokoh-tokoh yang memberi sumbangan luar biasa bagi bangsa Indonesia. Kontribusi positif-konstruktif pesantren ini dilengkapi dengan tampilnya KH. Abdurrahman Wahid sebagai presiden RI ke-4.

Peran keberhasilan beliau ini dengan sendirinya menempatkan pesantren dalam lembaran dokumentasi berharga bagi bangsa. ${ }^{2}$ Awalnya, pesantren lebih dikenal sebagai lembaga pendidikan Islam, lembaga yang dipergunakan untuk penyebaran agama dan tempat mempelajari agama Islam. Selanjutnya lembaga ini selain sebagai pusat penyebaran dan belajar agama mengusahakan tenaga-tenaga bagi pengembangan agama. Agama Islam bukan hanya mengatur masalah amalan-amalan peribadatan, atau bukan hanya mengatur hubungan hamba dengan tuhannya, melainkan juga akhlak orang dalam berhubungan

Jamal Ma'mur Asmani, Dialektika Pesantren Dengan Tuntutan Zaman, Abdul Munir Mulkhan, Menggagas Pesantren Masa depan, (Yogyakarta: Qirtas, 2006), 3. 
dengan sesama dan sang khalik. ${ }^{3}$ Dalam dekade 1980-an terjadilah perubahan yang cukup besar pada keberadaan pesantren sebagai sebuah sistem pendidikan tradisional yang mampu mengangkat harkat dan martabat bangsa dan negara. Kalau sebelumnya sistem pendidikan pesantren yang terdapat dalam pesantren dikenal sebagai bentuk sistem pendidikan non sekolah, namun kemudian hadir bentuk-bentuk sistem pendidikan sekolah kedalam komunitas pesantren, mulai dari madrasah Ibtidaiyah, Tsanawiyah, Aliyah, SLTP/SLTA umum, Perguruan Tinggi Keagamaan, bahkan perguruan tinggi Umum, tanpa menggusur sistem kelas bandongan yang selama ini dikenal dan menjadi budaya dalam dunia pesantren. ${ }^{4}$ Terjadinya perubahan pada diri pesantren tersebut, merupakan salah satu akibat dari sekian banyaknya sorotan, baik yang datang dari dalam maupun dari luar Islam, bahkan dari luar negeri yang notabene penduduknya non muslim.

Serta adanya bermacam-macam tujuan dan latar belakang dibalik adanya sorotan tersebut, ada yang positif, yaitu dengan tujuan mencari alternatif sistem

Suyoto, Pondok Pesantren dalam Alam Pendidikan Nasional, dalam M. Dawam Raharjo, Pesantren dan Pembaharuan, (Tk : Pustaka LP3ES Indonesia, 1998) 61.

Zubaidi Habillah Asyari, Moralitas Pendidikan Pesantren, (Yogyakarta : Kurnia Alam Semesta, 1996) 11. 
pendidikan yang ada di pesantren sudah dinilai tidak sesuai dengan tuntutan zaman bahkan dirasa tidak benar, sehingga pesantren merasa terangsang dan merenovasi untuk berbenah diri dengan mencari dan merubah sistem yang dianggap perlu diganti. Lebih lanjut Menteri Agama Republik Indonesia mengatakan bahwa : Pesantren memiliki fungsi sebagai berikut :

a. Sebagai lembaga pendidikan yang meletakkan transfer ilmu-ilmu agama (tafaqquh fidin) dan nilainilai Islam (Islamic Values).

b. Sebagai lembaga keagamaan yang melakukan kontrol social (Social Control).

c. Sebagai lembaga keagamaan yang melakukan rekayasa social (Social Engineering). 5

Sorotan lain yang ada selain tersebut di atas, adalah sorotan yang bagi pribadi merupakan ungkapan dan penilaian yang terlalu berlebihan, yaitu, pesantren dikatakan sebagai sebuah lembaga pendidikan yang mubadzir dan menghambat kemajuan, oleh karenanya hal yang terdapat di pondok pesantren sangat perlu untuk diadakan perombakan total. ${ }^{6}$ Terutama pada sistem pendidikannya, agar lebih sejalan dan dianggap berkesinambungan dengan tujuan yang mencakup

Peraturan Pemerintah Nomor 55 Tahun 2007 tentang Pendidikan Agama dan Kegamaan.

Ahmad Zaini, Dunia Pemikiran Kaum Santri, (Yogyakarta: LKPSM NU DIY, 1995) 85 
semua aspek pendidikan baik aspek spiritual, intelektual maupun emosional. Sehingga output pondok pesantren benar-benar tidak dipertanyakan mengenai aspek kapasitas keilmuannya, seperti: Imam Nawawi Al-Bantani dan Mahfud At-Termasi, yang dikenal sebagai seorang intelektual pesantren, atau Syekh Kholil Bangkalan, K.H.R. Asnawi Kudus, dan K.H. M. Hasyim Asy'ari, yang sangat populer disebut sebagai ahli strategi pesantren.

Mereka adalah sosok dari pondok pesantren, dimana kemasyhuran ilmunya bukan hanya berkibar di tingkat nasional melainkan berkaliber internasional.7 Kondisi tersebut merupakan bentuk kurang seimbangnya dari model pendidikan yang selama ini berjalan di masyarakat. Sehingga para pakar dan praktisi pendidikan baik yang ada di luar pondok pesantren maupun yang terdapat dalam komunitas pondok pesantren sendiri, mulai menyadari akan banyaknya problem dalam pendidikan (pondok pesantren), yang dapat dikatakan kurang berkembang dalam beradaptasi dan bersosialisasi dengan era masa kini. Sehingga model pendidikan lama yang sudah tidak relevan lagi dengan tuntutan zaman ini, hanya akan mencetak out-put santri yang setengah-setengah, lemah

Abdurrahman Mas'ud, Intelektual Pesantren; Perhelatan Agama dan Tradisi, (Terjemah), ( Yogyakarta: LkiS, 2004) 4. 
akan penguasaan metodologi dan rendahnya daya kreatifitas santri dalam mengaktualisasikan kemampuan intelektualnya.

Secara tidak langsung, hal itu merupakan implikasi dari pada pengembagan keilmuan dalam tradisi pondok pesantren itu sendiri. Jika diruntut dari sejarahnya, dapat dimaklumi bahwa tradisi intelektual pondok pesantren terbentuk dari epistemologi keilmuan yang berlandaskan pada berbagai kitab kuning sebagai referensi utama pondok pesantren. Pada umumnya kitab-kitab tersebut terfokus pada figh, nahwu-sharaf dan tasawwuf. Sehingga kajian kitab kuning yang dikembangkan di pondok pesantren lebih berorientasi pada aspek legal formal dari pada aspek substansial.

Materi yang dikaji lebih banyak bersifat parsial dan terkesan tidak komprehensif dalam menggali ilmuilmu keIslaman yang berhasil digali dan dikembangkan sejak fase Abbasyiah terdahulu . Terlebih lagi proses belajar mengajar yang dikembangkan masih saja berorientasi pada materi, dan bukan pada tujuan. Proses pembelajaran dianggap telah berhasil bila santri sudah menguasai betul materi-materi yang tersalurkan dari kitab kuning dengan hafalan yang baik. Para lulusan santri kelak akan mampu menerjemahkan dan mensosialisasikan materi-materi yang telah disalurkan 
ketika berhadapan dengan arus dinamika masyarakat yang bervariasi. Hal ini merupakan pertanyaan yang belum dapat dijawab secara pasti, sebab potensi dasar pondok pesantren untuk pemberdayaan dan transformasi telah hidup sedemikian rupa. Sehingga khazanah ilmu-ilmu keIslaman yang mereka tangkap dengan kerangka itu menelorkan pemahaman parsial.

Dengan adanya kondisi seperti itu, yang menjadi upaya mendasar dapat dicapai melalui pengembangan wawasan berpikir di kalangan pondok pesantren, dengan memperkaya basis materi metodologi keilmuan selain basis materi yang selama ini digeluti dan diminati. Salah satu kekurangan dunia pesantren hingga dewasa ini adalah minimnya pengembangan pemikiran analitis dalam tradisi membaca teks kitabkitab kuning. Sebaliknya, tradisi membaca kitab kuning yang semakin berkembang adalah aspek hafalan dan pemahaman tekstualnya yang terkenal sangat ketat. Padahal sebuah komunitas dapat mengembangkan kemandirian berpikir, apabila tradisi membaca yang dikembangkan membuka seluas-luasnya dinamisasi penalaran. Untuk itu sebagai solusi terpenting yang dapat diambil seharusnya dapat berangkat dari epistimologi keilmuan dengan melakukan reorientasi makna dan tujuan dalam sistem pendidikan pondok 
pesantren tersebut.8Santri adalah elemen bangsa yang sedang meniti masa depannya melalui lembaga pesantren. Mereka adalah generasi bangsa yang dinantinanti oleh masyarakatnya di kemudian hari saat kembali ke kampung halamannya. Harapan tersebut tentu tidak hanya dielu-elukan oleh masyarakat sekitarnya, melainkan juga bangsa yang sedang terpuruk.

\section{B. Pengembangan Pendidikan Pesantren}

Sebagai dari masyarakat dunia, santri juga sedang dihadapkan pada tantangan masa depan yang kompleks. Tantangan santri sekarang tentu berbeda dengan santri pada era tahun 1970-an. Pendidikan harus dijadikan sebagai penyaring antara kekuatan positif dan negatif dari perkembangan pengetahuan dan teknologi. ${ }^{9}$ Progresif dalam ilmu pengetahuan dan teknologi mengantarkan bangsa Indonesia ke masa transisi yang sangat sulit. Kehidupan politik, ekonomi dan sosial sangat berbarengan dengan kemajuan ilmu pengetahuan dan teknologi perubahan ini perlu dihadapi sangat cepat dan tepat sehingga masyarakat

\footnotetext{
Said Agiel Siradj, ed, Wacana Pemberdayaan dan Transformasi Pesantren dalam Pesantren Masa Depan (Bandung: Pustaka Hidayah, 1999) 204.

Ridwan Idris, Perubahan Budaya dan Ekonomi Indonesia dan Pengaruhnya terhadap Pendidikan, Lentera Pendidikan Vol 14 No. 2 Desember (2014), 219-231
} 
kita akan menjadi sasaran negatif dari sebuah teknologi, akan tetapi dapat menjadi pemain untuk mengarahkan ilmu pengetahuan dan teknologi yang ada dimanfaatkan menjadi kekuatan yang dapat membangun masyarakat Indonesia yang lebih baik. Idealnya untuk dapat memberikan arah yang jelas terhadap perubahan ini. Meskipun tak kalah beratnya, namun santri zaman dahulu belum terlalu menghadapi tantangan krisis ruhani seperti yang terjadi saat ini. Pada era pasca kemerdekaan hingga menjelang tahun 1990-an, santri dibebani tugas agar ia bisa menjadi contoh di masyarakat sekitarnya. Diantara mereka termotivasi mondok di pesantren hanya karena ingin beragama secara baik dan benar. Namun, kini santri dihadapkan pada problem globalisasi yang semakin cepat.

Mereka harus menguasai ilmu dan teknologi secara baik dan benar sekaligus mampu memberi nilai atas ilmu dan teknologi yang ia kuasai. Godaan duniawi yang menawarkan beragam kemewahan dan keserakahan juga sudah tampak di depan mata. Nurcholis khawatir kalau-kalau pesantren kehilangan keampuhannya dalam menunaikan tugas moral. Sebab sebagai sumber nilai pengembangan dan pembinaan sumber nilai, ajaran agama yang ditekuni di pesantren 
berfungsi pengembangan sumber tugas moral. ${ }^{10}$ Dengan agama yang tertanam sebagai peran dalam mengatasi persoalan-persoalan yang muncul dan tidak dapat dipecahkan secara empiris, berguna sebagai aspek yang harus dipelajari untuk mengetahui peran agama dalam masyarakat, diantaranya santri ketika keluar memiliki ketenangan jiwa, sosial dan kepribadian sehingga semua aspek saling ketergantungan dalam kehidupan. ${ }^{11}$ Seperti kita ketahui sistem pendidikan pondok pesantren dibanggakan karena tidak terpaku pada penimbunan pengetahuan dan pengasahan otak belaka, tetapi juga mementingkan pembinaan kepribadian, karakter manusia dan tingkah laku. Dalam melatih etika, Skinner menjelaskan bahwa istilah shaping, yaitu upaya secara bertahap untuk membentuk tingkah laku, mulai bentuk yang paling sederhana sampai bentuk yang paling kompleks. oleh karena itu pondok pesantren merupakan lembaga pendidikan yang berorientasi pada agama, maka nilai-niali etika (akhlak) yang dijadikan pegangan adalah bersumber dari falsafah keagamaan yang harus diikuti oleh mereka yang terproses di dalamnya secara menyeluruh tanpa syarat. Adapun dalam pembinaan kepribadian santri

\footnotetext{
$10 \quad$ Nurcholis Madjid, Bilik-Bilik Pesantren: Sebuah Potret Perjalanan (Jakarta: Paramadina, 1997), 106

11 Dadang Kahmad, Sosiologi Agama, (Bandung: Rosda, 2002), 130-136
} 
yang berlangsung di pondok pesantren secara garis besarnya adalah: Penanaman nilai-nilai, Pembinaan dengan pengajaran kitab-kitab akhlak, dalam penanaman nilai-nilai akhlak dengan pengajaran kitakitab, secara tradisional sistem pendidikan yang diterapkan di pesantren, memilahkan secara tegas aspek pengembangan intelektual dan aspek pembinaan kepribadian. Untuk membina kepribadian anak didik (santri), di pondok pesantren memakai kitab-kitab akhlak seperti Akhlakul Banat, Akhlakul Banin dan Kitab tafsir Qur'an yang menafsirkan beberapa ayat Al-Qur'an dan hadits yang berkaitan dengan budi pekerti dan kewajiban kewajiban seorang Muslim. Membiasakan Hidup Berakhlak, Tingkah laku yang menyimpang terdapat pada individu sebagai hasil pengalaman pengkondisian yang keliru (faulty of conditioning). Karena itu tugas pertama dari seseorang adalah menghapus tingkah laku yang menyimpang, dan membentuk tingkah laku baru yang layak melalui pemerkuatan atas tingkah laku yang layak itu. Sikap jiwa agama yang bersungguh-sungguh, jauh dari perkataan yang menghinakan dan kekesalan. Jika seseorang menderita cobaan atau musibah, ia tidak akan mengeluh karena di samping penderitaan itu, ia mempunyai jalan untuk terlepas dari pada kesukaran 